\title{
PROPRIOCEPTIVE EXERCISE WITH BOSU MAXIMIZES ELECTROMYOGRAPHIC ACTIVITY OF THE ANKLE MUSCLES
}

\author{
EXERCÍCIO PROPRIOCEPTIVO COM BOSU MAXIMIZA ATIVIDADE \\ ELETROMIOGRÁFICA DOS MÚSCULOS DO TORNOZELO
}

\author{
Frederico Balbino LIZARDO ${ }^{1}$; Gabriela Moreira RONZANI ${ }^{1}$; Lucas Resende SOUSA ${ }^{1}$; \\ Daniela Cristina de Oliveira SILVA ${ }^{1}$; Lázaro Antônio dos SANTOS ${ }^{1}$; Paulo Ricardo LOPES ${ }^{1}$; \\ Fausto BÉRZIN ${ }^{2}$; Delaine Rodrigues BIGATON ${ }^{3}$ \\ 1- Laboratory in Kinesiologic Electromyography, Federal University of Uberlandia, Uberlândia, MG, Brazil, frederico@ufu.br; 2- \\ Piracicaba Dental School, State University of Campinas, Piracicaba, SP, Brazil; 3- Postgraduate Program in Physiotherapy, Methodist \\ University of Piracicaba, Piracicaba, SP, Brazil.
}

\begin{abstract}
Ankle sprains are commonly related to sporty activities and often associated with decreases in sensorimotor control, including proprioception, muscle strength and balance. The use of unstable surfaces in the fields of rehabilitation and general fitness has been shown to be effective in increasing the sensory efficiency of soft tissues that stabilize the knee and ankle as well as improving the agonist-antagonist co-contraction. The aim of this study was to analyze the EMG activity of the ankle muscles - the tibialis anterior (TA), peroneus longus (PL) and medial head of the gastrocnemius (GM) during proprioceptive exercises using the BOSU compared to other devices traditionally used (balance platform, trampoline and proprioceptive disk). Eleven male volunteers were recruited and data collection was performed using single differential surface electrodes. The EMG signal was recorded and expressed as root mean square, which was normalized by the maximum voluntary isometric contraction. The data were subjected to parametric statistical analysis, using the analysis of variance (ANOVA) for repeated measures. The results showed that the BOSU provided greater activity in the ankle muscles than the most proprioceptive devices, accordingly, the BOSU is a device that should be employed to diversify programs of prevention/rehabilitation for lower limb injuries, preferentially in advanced stages of these approaches.
\end{abstract}

KEYWORDS: Balance platform. Proprioceptive disk. Trampoline. Electromyography.

\section{INTRODUCTION}

The term proprioception is used to describe all information originated in neural proprioceptors of the joints, muscles, tendons, ligaments and capsules, which are sent to the central nervous system through afferent pathways, consciously or unconsciously, in addition to biomechanical relationships of joint tissues, which can influence the muscle tone, postural balance and joint stability (ANTES; KATZER; CORAZZA, 2008).

Ankle sprains are among the most common musculoskeletal injuries, and many individuals with ankle sprains develop chronic ankle instability (FEGER et al., 2015). Ankle sprains are commonly related to sporty activities and often associated with decreases in sensorimotor control, including proprioception, muscle strength and balance (STEIB et al., 2013).

It is estimated that one ankle inversion injury occurs for every 10,000 people per day and ankle ligament injuries represent $7 \%$ to $10 \%$ of all cases admitted to the emergency services of hospitals (RENSTROM; LYNCH, 1999). Also, ankle sprains represent approximately $15 \%$ of all athletic injuries in high school students and about
800,000 visits per year (NEEDLE et al., 2013). Thus, the proprioceptive training is recommended to improve balance and neuromuscular control of the ankle and to restore the motor functions of the lower limbs (RENSTROM; LYNCH, 1999; OLIVEIRA et al., 2012).

Proprioceptive exercises are performed with different unstable platforms using the mechanical and sensory properties of ligaments, joint capsule and integrated activity of the muscles around the joint to improve joint stability (FERREIRA et al., 2011). Changes in the myoelectrical characteristics of the muscles in different activities can be identified by means of electromyography, which is the study of muscle function through the investigation of the electrical signal emanating from the muscle (BASMAJIAN; DE LUCA, 1985).

In recent years, several commercial products have been developed and used in proprioceptive training (FRANCO; AMAT; LÓPEZ, 2013), leading researchers to analyze the electrical activity of the ankle and thigh muscles in proprioceptive exercises with different devices (MARTINS et al., 2014; CALLEGARI et al., 2010), including the Both Sides Utilized (BOSU) balance trainer (LAUDNER; KOSCHNITZKY, 2010). The BOSU 
is an instrument of unstable surface that has a solid platform base with a rubber inflatable dome, similar to a gym ball halved, which has become quite popular in fitness centers and physical therapy clinics (LAUDNER; KOSCHNITZKY, 2010; BEHM; SANCHEZ, 2012).

Laudner and Koschnitzky (2010) evaluated the electrical activity of the ankle muscles using the BOSU, with the platform resting on the floor or facing up, and found no significant differences between the two sides. Although many proprioceptive devices are common in both physical therapy clinics and athletic training rooms, there are currently little data comparing the level of electromyographic (EMG) activity of the ankle muscles using the BOSU over other traditional devices, such as balance platform, trampoline and proprioceptive disk.

The use of unstable surfaces in the fields of rehabilitation and general fitness has been shown to be effective in increasing the sensory efficiency of soft tissues that stabilize the knee and ankle as well as improving the agonist-antagonist co-contraction (BEHM et al., 2010). Thus, it can be expected that the use of BOSU provides greater EMG activity in the ankle muscles compared to other devices.

The aim of this study was to analyze the EMG activity of the ankle muscles - the tibialis anterior (TA), peroneus longus (PL) and medial head of the gastrocnemius (GM) during proprioceptive exercises using the BOSU compared to other devices traditionally used (balance platform, trampoline and proprioceptive disk). Thus, by providing a quantitative measure of muscle activation in different proprioceptive exercises, it can be assumed a theoretical basis for targeting programs of prevention and rehabilitation for joint injuries or neuromuscular disorders of the lower limbs.

\section{MATERIAL AND METHODS}

\section{Design and Participants}

This is an experimental-quantitative study that was developed in the Laboratory in Kinesiologic Electromyography of the Federal University of Uberlandia, Brazil and approved by the Research Ethics Committee (number 303.825) of the Institution.

Eleven male volunteers (mean \pm standard deviation for age $23 \pm 2.1$ years; body mass $70.5 \pm$ $10.3 \mathrm{~kg}$; height $176.3 \pm 6.9 \mathrm{~cm}$ ) were enrolled in this study. As inclusion criteria, all subjects should be practicing regular physical activity (resistance and/or cardiovascular training during at least $30 \mathrm{~min}$ three times per week) (OLIVER et al., 2010), considered to be physically active according to the International Physical Activity Questionnaire (IPAQ short version) and have a body mass index (BMI) value considered as ideal (18.5 to 24.9).

The exclusion criteria were volunteers with history of musculoskeletal disorders of the lower limbs or any other disorder that might interfere with the execution of the exercises, history of balance training, and the use of anti-inflammatory, analgesic or myorelaxant drugs that could influence the muscle activity.

The sample size calculation was based on a pilot study with four volunteers, using the root mean square (RMS) EMG parameter of the muscle tibialis anterior and the GPower 3.1 software, with 80\% power and $\alpha=0.05$. This calculation gave a minimum sample size of $n=10$ for this study.

\section{Electromyographic activity}

The EMG activity was performed using a computerized electromyograph (Myosystembr1 P84, DataHominis Tecnologia Ltda., Uberlândia, MG, Brazil), which was developed according to standards of the International Society of Electrophysiology and Kinesiology (ISEK), with input impedance of $1015 \mathrm{Ohms}$, analogic/digital converter with 16-bit resolution, Butterworth filters and integrated rechargeable battery. The EMG signals were collected and later processed using the Myosystem Br1 software version 3.5.6 (DataHominis Tecnologia Ltda.). The sampling frequency was $2,000 \mathrm{~Hz}$ per channel throughout the data collection and electromyographic signals were subjected to a $20 \mathrm{~Hz}$ high-pass and $500 \mathrm{~Hz}$ low-pass filters, following the recommendations of SENIAM (Surface Electromyography for the Non-Invasive Assessment of Muscles).

The EMG signals were captured using single differential surface electrodes (DataHominis Tecnologia Ltda.), with a gain of 20 times and rejection reason at common mode of $92 \mathrm{~dB}$ at 60 $\mathrm{Hz}$, composed of two parallel rectangular bars of silver (10 mm long x $1 \mathrm{~mm}$ wide) and spaced 10 $\mathrm{mm}$ apart. The preparation of volunteers consisted of shaving and cleaning the skin with $70 \%$ alcohol. Surface electrodes were placed on tibialis anterior (TA), peroneus longus (PL) and medial head of the gastrocnemius (GM) muscles in accordance with previous recommendations of SENIAM (HERMENS; FRERIKS, 1999). Thus, for the TA muscle, electrodes were set to $1 / 3$ on the line between the ends of the head of the fibula and the 
medial malleolus. For the PL muscle, electrodes were positioned approximately $25 \%$ of a line drawn between the ends of the fibular head and the lateral malleolus, and for the GM muscle, electrodes were placed in its most prominent portion.

After placement of the electrodes the volunteers performed specific movements, according to the muscular functions, to verify the correct positioning and examine the quality of the EMG signal (KONRAD, 2005). A reference electrode (DataHominis Tecnologia Ltda.) was used, consisting of a rectangular stainless steel plate (30 x $40 \mathrm{~mm}$ ), which was attached on the skin of the ulnar styloid process in the right antimere (OLIVEIRA et al., 2012).

\section{Devices}

The devices used were the BOSU balance trainer, balance platform, trampoline and proprioceptive disk (Figure 1). The BOSU (BOSU Balance - ISP ELETROMEDICA, Santa Tereza do
Oeste, PR, Brazil) is versatile and sturdy, supports up to $200 \mathrm{~kg}$, has $55 \mathrm{~cm}$ diameter and combines a solid platform base with a rubber inflatable dome. The BOSU was inflated to a recommended height of approximately $25.4 \mathrm{~cm}$ and was used with the platform resting on the floor (BOSU) and upwards (inverted BOSU).

The balance platform is a device made of steel with a central platform attached by galvanized chains and a floor covered with non-slip material (equilibrium proprioceptive balancing FISIOBRAS, Curitiba, PR, Brazil).

The proprioceptive disk (Disco Flex Multiuso - MERCUR S.A., Santa Cruz do Sul, RS, Brazil) has $30 \mathrm{~cm}$ and was inflated so that the surfaces (both sides of the disk) remain flat, according to the manufacturer's recommendations. The trampoline is a rounded structure covered with resistant and malleable canvas subject to deformation, which supports up to $150 \mathrm{~kg}(96 \mathrm{~cm}$ trampoline - professional - FISIOBRAS).
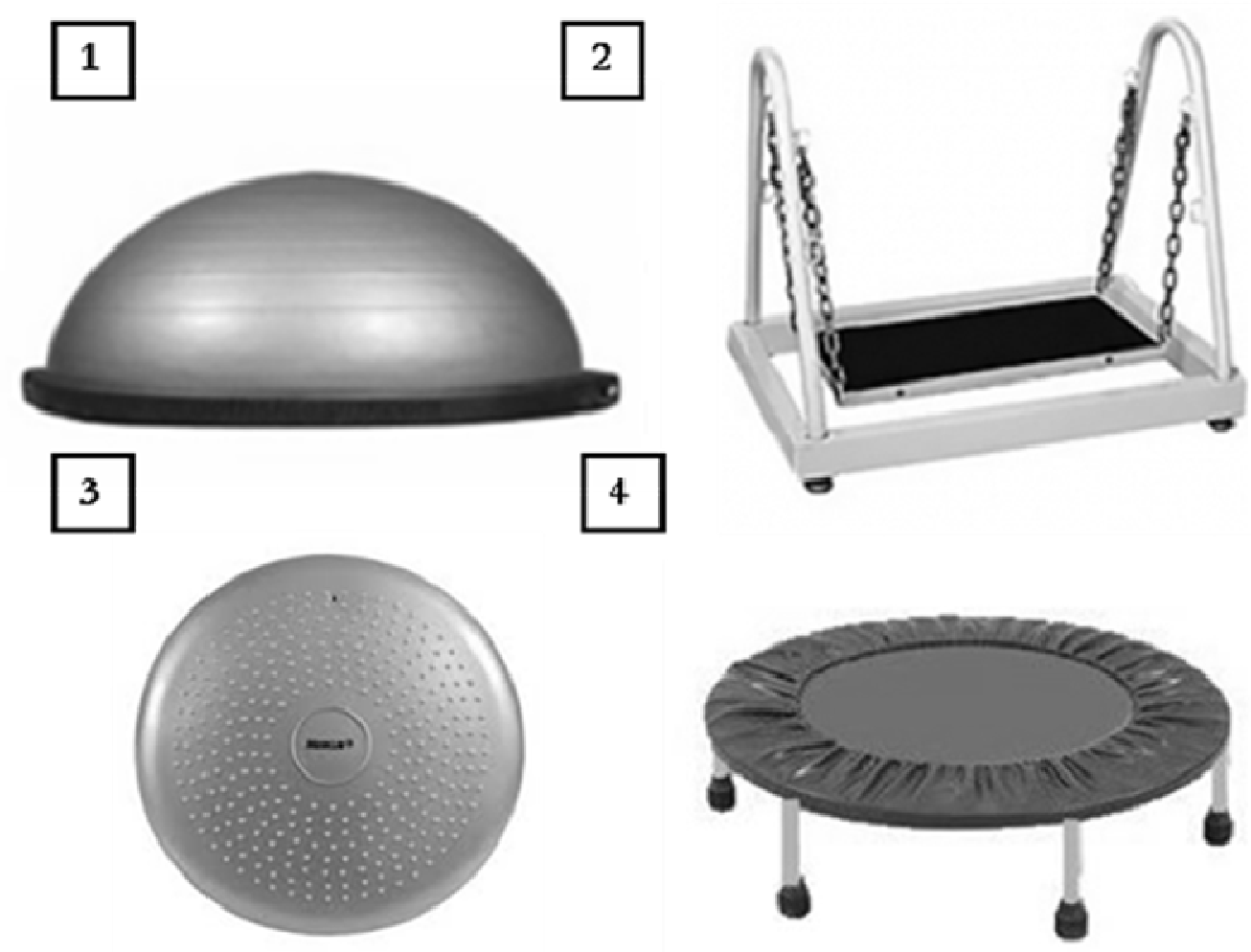

Figure 1: Proprioceptive devices: BOSU (1), balance platform (2), proprioceptive disk (3) and trampoline (4).

\section{Experimental procedure}

Data collection was performed into two different days. In the first, the volunteers underwent a physical evaluation (height and weight) and answered to an international physical activity questionnaire - short version. Later, the participants were familiarized with the exercises and the maximum voluntary isometric contraction (MVIC). EMG signals were collected after a week, by performing two 5-sec MVICs with 3-min rest period (BROWN, 2008) and further normalization of data. 
After 5-min rest of the MVICs, the subjects performed all proprioceptive exercises.

The MVIC tests of the ankle muscles were performed by volunteers according to their muscle functions and following the recommendation of previous studies (HERMENS; FRERIKS, 1999; LAUDNER; KOSCHNITZKY, 2010). After normalization of the signals, the crude RMS values expressed in microvolts were replaced by normalized values of RMS (RMSn) that were expressed as percentage of MVIC (\% MVIC).

Subsequently, each subject performed three repetitions for each proprioceptive exercise, with a 10 -sec time for the collection of EMG signals on each device, using a 30 -sec rest between the repetitions and 1-min rest between the different exercises. The order of execution of the proprioceptive exercises (BOSU, inverted BOSU, balance platform, trampoline, and proprioceptive disk) was chosen randomly among the volunteers by means of a draw. The procedures for the assessment of muscle activity were performed in the dominant lower limb that was selected through a question for each subject on your own to kick a ball (LAUDNER; KOSCHNITZKY, 2010).

During the exercises, participants were instructed to stand barefoot with supporting of the dominant limb and eyes open, hands on his hips and the flexed opposite leg without touching the supporting leg, which should be slightly bent (LAUDNER; KOSCHNITZKY, 2010). In order to obtain a standardization and greater muscle activation, it was chosen an angle of $30^{\circ}$ for supporting leg flexion, controlled by a universal goniometer (CARCI, Indústria e Comércio de Aparelhos Cirúrgicos e Ortopédicos Ltda., São Paulo, SP, Brazil). According to Ferreira et al. (2009) the chosen position of the knee provides greater joint instability, preventing the position of terminal extension and hence a stable joint position is achieved through the mechanism of lock and bolt.

The subjects were advised to focus on a specific point in front, and if at any time the subject changed this posture, the data were discarded and the task was repeated (LAUDNER; KOSCHNITZKY, 2010).

\section{Data analysis}

For signal analysis, the crude values of root mean square (RMS) obtained from each muscle were processed and analyzed using the Myosystem br1 software (version 3.5.6) from a 3-sec time window central in the MVIC and a 5-sec window central on proprioceptive exercises, corresponding to the middle section of the EMG signal. The RMS values of each muscle were calculated from the average of three repetitions of each exercise and normalized in terms of percentage of the greater crude RMS value obtained from two sequences of MVIC.

The values of intraclass correlation coefficients (ICC) in MVIC tests were 0.907, 0.707, and 0.765 for the TA, PL and GM muscles, respectively. The analyzes of EMG signals were conducted individually for investigation of recording and signal routine, and only the signs that have shown no interference of any kind were considered in the study. All collections of the EMG signal of the experimental procedure were preceded by real-time analysis of the frequency spectrum, which allows us to observe any interference that may be present in the collections (AGUIAR, 2006). The mean ICC values of the EMG signal during the proprioceptive exercises were 0.712, 0.594, and 0.862 for the TA, PL and GM muscles, respectively.

\section{Statistical analysis}

The statistical analysis was performed using the GraphPad Prism software version 5.0 (GraphPad Software Inc., San Diego, CA, USA). The ShapiroWilk test was used to assess the normality of the data and subsequently parametric tests were used in all analyzes. The repeated measures analysis of variance (ANOVA) was used to compare the means of normalized RMS values (RMSn) obtained from the same muscle in different exercises, and the Bonferroni multiple comparison test to see where there was a difference. The level of significance was set at $5 \%(p<0.05)$. All results are expressed as mean and standard deviation. The effect size (ES) was calculated using the Cohen's description for interpretation $(\mathrm{ES}=0.2$, small; $\mathrm{ES}=0.5$, medium; and $\mathrm{ES}=0.8$, large).

\section{RESULTS}

The RMSn values (expressed in \% MVIC) of the EMG activity of TA, PL, and GM muscles during different proprioceptive exercises are shown in Table 1 and Figure 2.

For TA activity, the RMSn values in BOSU and inverted BOSU were greater than in the balance platform $(p<0.001 ; \quad \mathrm{ES}=1.72$ and $\mathrm{ES}=1.53$, respectively) and trampoline $(p<0.001 ; \mathrm{ES}=2.12$ and $\mathrm{ES}=1.74$, respectively). The EMG signal of the TA muscle was greater in inverted BOSU compared with the proprioceptive disk $(p<0.05 ; \mathrm{ES}=0.83)$. Moreover, RMS values of TA muscle in proprioceptive disk were greater than in the trampoline $(p<0.05 ; \mathrm{ES}=1.25)$. 
The PL activities in BOSU and inverted BOSU were greater than in the balance platform $(p<0.001 ; \mathrm{ES}=1.32$ and $\mathrm{ES}=1.45$, respectively) and trampoline $(p<0.001 ; \mathrm{ES}=1.52$ and $\mathrm{ES}=1.67$, respectively).
The GM activities in BOSU and inverted BOSU were greater than in the balance platform $(p<0.05 ; \mathrm{ES}=0.95$ and $\mathrm{ES}=1.37$, respectively) and trampoline $(p<0.001 ; \mathrm{ES}=1.29-1.91)$. Also, the RMSn values of GM muscle in disk were greater than in the trampoline $(p<0.05 ; \mathrm{ES}=1.25)$.

Table 1. RMS values of the tibialis anterior (TA), peroneus longus (PL), and medial head of the gastrocnemius (GM) muscles during proprioceptive exercises using different devices. Uberlândia-MG, 2015.

\begin{tabular}{lccc}
\hline & \multicolumn{3}{c}{ Muscles } \\
\cline { 2 - 4 } Devices/Exercises & TA & PL & GM \\
\hline BOSU & $33.9 \pm 7.9$ & $51.4 \pm 15.8$ & $41.5 \pm 16.0$ \\
Inverted BOSU & $38.1 \pm 15.4$ & $52.4 \pm 14.7$ & $44.2 \pm 11.6$ \\
Balance platform & $18.0 \pm 10.4$ & $31.5 \pm 14.1$ & $28.4 \pm 11.3$ \\
Trampoline & $16.1 \pm 8.9$ & $30.9 \pm 10.6$ & $25.1 \pm 8.2$ \\
Proprioceptive disk & $27.5 \pm 9.3$ & $42.1 \pm 9.4$ & $37.1 \pm 10.8$ \\
\hline
\end{tabular}

RMS values were normalized (RMSn) and expressed in percentage of maximum voluntary isometric contraction (\% MVIC). Data represent the mean and standard deviation.

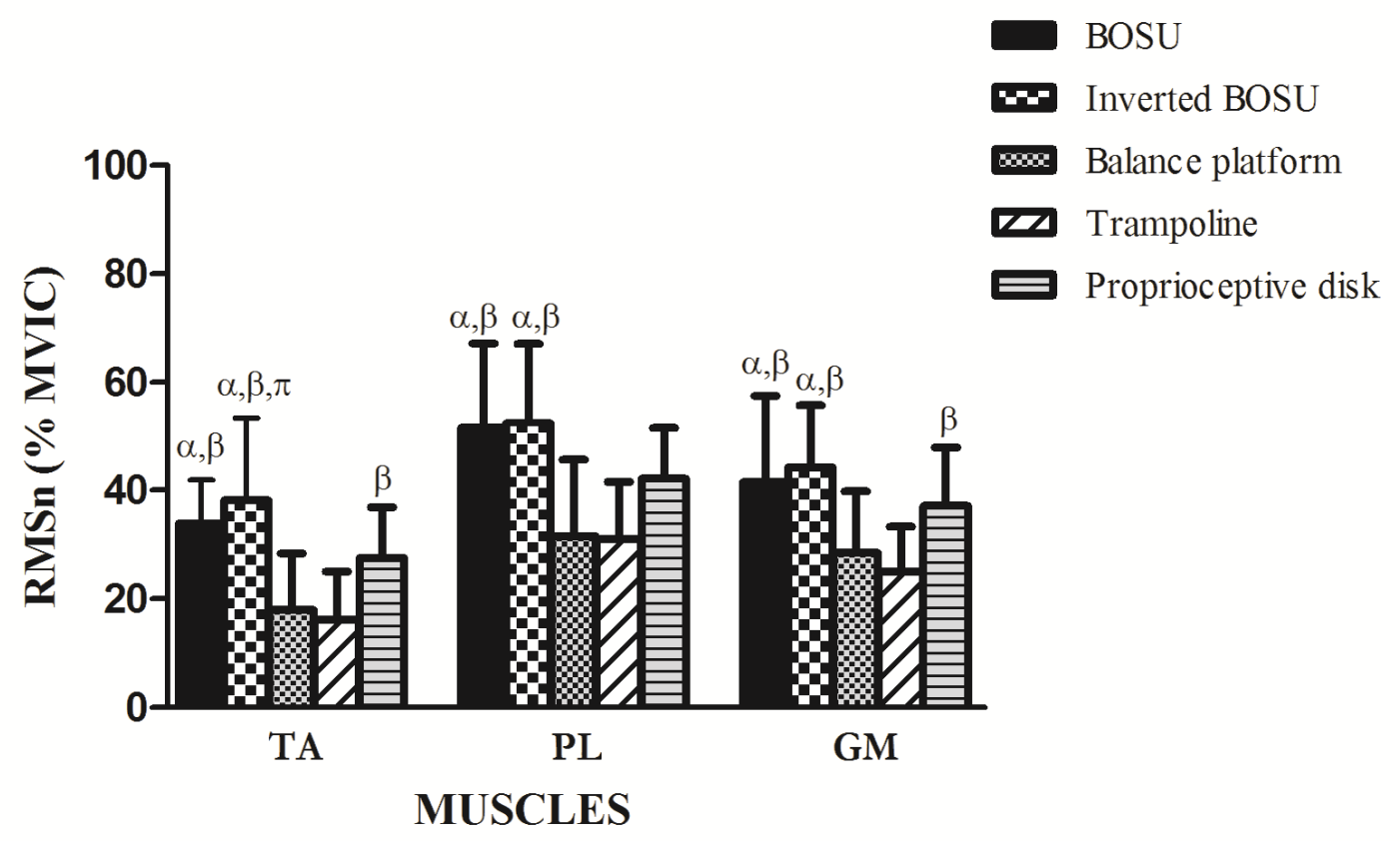

Figure 2: Comparison of the RMSn values of the tibialis anterior (TA), peroneus longus (PL), and medial head of the gastrocnemius (GM) muscles between different proprioceptive exercises with BOSU, inverted BOSU, balance platform, trampoline and proprioceptive disk. RMSn values were expressed as percentage of maximum voluntary isometric contraction (\% MVIC). Bars indicate the mean and standard deviation. ${ }^{\alpha}$ Significantly greater in comparison with the balance platform; ${ }^{\beta}$ Significantly greater in comparison with the trampoline; ${ }^{\pi}$ Significantly greater in comparison with the proprioceptive disk $(p<0.05)$.

\section{DISCUSSION}

The results of the present study demonstrated that the BOSU provided greater EMG activity in the ankle muscles compared to most proprioceptive exercises. According to Peccin and Pires (2003), exercises on unstable soils generate rapid changes in the length of the ankle ligaments by stimulating the ankle in multiple planes of motion, generating afferent stimuli and reflex motor responses to produce rapid joint stability. Thus the objective of this training is to induce unpredicted disturbances, stimulating the reflex stabilization and production of agonist-antagonist co-contraction. 
The inclusion of proprioceptive exercises in prevention and rehabilitation programs should not be based on casual evidence without an understanding of the neuromuscular mechanisms. This understanding is necessary and very important for professionals in sports medicine for standardization of programs for prevention and rehabilitation of athletes (FERREIRA, 2009).

Thus, the results of the present study are very important for sports athletes in general, and especially for physical therapists and physical education professionals, in providing data on the EMG activity of the TA, PL, and GM muscles in different unstable surfaces that are commonly used in programs for prevention and rehabilitation of joint injuries or neuromuscular disorders of the lower limb or sports training, becoming a useful tool for guiding these programs.

Regarding the different devices, the results of this study showed that EMG activity of all muscles analyzed were higher in BOSU and inverted BOSU than in the balance platform and trampoline and with no significant differences in most of the muscles among BOSU, inverted BOSU and disk.

There are no studies comparing the BOSU with these devices; however, it is important to highlight that the disk is similar to BOSU regarding its inflatable structure and high degree of difficulty and instability, and it should be used at advanced stage in proprioceptive training.

The activity of ankle muscles in different unstable soils (trampoline, balance platform and proprioceptive disk) was compared to stable soils, demonstrating that trampoline was the unstable soil that had lower EMG activity in all muscles analyzed, but with no significant differences to stable soil (FERREIRA et al., 2009). Also, a greater muscle activity was noted in the disk followed by the balance platform, which showed intermediate activity in all muscles analyzed. The results of the present study agree in part with these findings, since the muscle recruitment with the disk was higher than in trampoline; however, in most muscles evaluated, there were no significant differences between the disk and balance platform. As the data of Ferreira et al. (2009) were not normalized, such factor may explain the differences found and be a limiting factor in this study.

The EMG activity of the GM (lateral head) and TA muscles was investigated using balance platform, balance board, trampoline and ground, demonstrating greater muscle recruitment in balance platform as well as higher degree of difficulty in maintaining balance (CALLEGARI et al., 2010). In the present study the balance board and the ground were not evaluated; however, there were no significant differences in muscle activity exhibited by the TA, PL, and GM muscles in balance platform and trampoline. These contrasting findings may be explained because the level of physical activity and experience of volunteers in relation to proprioceptive training were not considered, nor the PL muscle, which is also important in stabilizing the ankle, was evaluated in this previous study (CALLEGARI et al., 2010).

It should be noted that during exercises with balance platform and trampoline, the volunteers had a higher level of difficulty in the first device, but this was not significantly relevant in the EMG activity of the ankle muscles. Thus, it would be interesting to evaluate the recruitment of stabilizing muscles of the trunk in different proprioceptive exercises to verify if the higher degree of difficulty in maintaining balance causes increase in the EMG activity of these muscles.

A previous study was conducted in order to verify which side of the BOSU (platform up or down) produces greater EMG activity in the ankle muscles and showed that there were no significant differences between the two sides (LAUDNER; KOSCHNITZKY, 2010). The results of the present study corroborate with these previous findings and highlight that the BOSU is a device that can be used to diversify balance training or during the rehabilitation of lower limb injuries.

Interestingly, data obtained with inverted BOSU (Table 1) demonstrated higher values of EMG activity compared to BOSU, even with no significant differences. It should be emphasized that these data can be explained by the higher level of difficulty and instability in exercises with inverted BOSU, demonstrating its effectiveness in muscle recruitment and that this device should be used in advanced stages within a program for prevention or rehabilitation of lower limb injuries.

Laudner and Koschnitzky (2010) demonstrated activation of the TA, PL and GM muscles around $40.5 \%, 48.1 \%$ and $49.2 \%$ with the BOSU, and $42.6 \%, 46.7 \%$ and $47.5 \%$ with the inverted BOSU, respectively. In the present study, it was verified a mean activation of approximately $35 \%, 51 \%$ and $42 \%$ for the TA, PL, and GM muscles, respectively, during both exercises with BOSU, showing similarity with the findings of these authors. These similarities can be explained by similar procedures used in the methodology and data normalization between the two studies.

According to Blackburn et al. (2003) proprioceptive exercises in closed kinetic chain 
cause co-contraction of various muscle groups around the ankle joint, simulating the functional activity and allowing the rehabilitation of specific sports. Also, the level of agonist-antagonist cocontraction may be more important for assessing muscle function in comparison with the activity of the isolated muscles. Thus, it is important to note the overall function of the TA, PL, and GM muscles as dynamic stabilizers of the ankle (NETTER, 2000) and to highlight the importance of the BOSU in the process of prevention and rehabilitation due to higher production of agonist-antagonist cocontraction in comparison with other devices.

The effect of balance training with BOSU for four weeks on postural control and specific functional tasks (time spent on BOSU, shuttle run agility test and vertical jump) was evaluated and showed an improved performance on these parameters; however, it is unclear whether these skills are transferable to leisure activities or sports performance (YAGGIE; CAMPBELL, 2006).

Based on these findings and the results of the present work, the use of BOSU in balance training provides benefits, but it is believed that the use of various stimuli (different devices) may be an important factor that can be observed two principles of sports training, that is, the biological individuality and progressive overload. The first states that the training should be developed on an individual basis to achieve the best results with respect to functional limitations of each subject, while the second supports the idea of a progressive increase in workload for constant improvement of physical fitness (EVANGELISTA; MACEDO, 2011). Therefore, the use of different devices in balance training is important to respect the difficulties and limitations of each volunteer and to provide a progressive overload from the distinct EMG records in each device.

In the present study we evaluated male subjects, relatively young, healthy, and physically active without ankle injury. Therefore, the results should be applied with care to different populations, because individuals with acute and chronic joint instability may display other muscle recruitment profile in different unstable soils, becoming a limiting factor in this work. Future studies should be conducted to make comparisons of the EMG activity in different groups, such as the elderly, sedentary or subjects with ankle injuries.

In order to improve balance using several exercises, the health professionals should consider five general rules before starting a preventive or rehabilitation work as follows: (i) exercises should be safe and challenging, (ii) stressing the various planes of motion, (iii) incorporating a multisensory approach, (iv) starting on stable surfaces with bilateral support, and (v) succeeding to unstable surfaces with unilateral support, progressing to functional exercises in sports (OLIVEIRA et al., 2012).

From the results of this study, in proprioceptive training used in preventive or rehabilitation programs, it would be interesting that the individual begins with trampoline followed by balance platform, advancing to the proprioceptive disk and, finally, using the BOSU to obtain greater muscle activation of the ankle. In addition, the BOSU should be preferentially used first with the platform in contact with the ground and then with the reversed platform (inverted BOSU), due to greater difficulty observed in the latter situation.

\section{CONCLUSION}

It can be concluded that the BOSU provided greater EMG activity of the ankle muscles in comparison to most proprioceptive devices, accordingly, the BOSU is a device that should be used to diversify programs for prevention or rehabilitation of lower limb injuries, especially in advance stages of these programs.

RESUMO: As entorses de tornozelo são comumente relacionadas com atividades desportivas e muitas vezes estão associados com diminuição no controle sensório-motor, incluindo a propriocepção, força muscular e equilíbrio. A utilização de superfícies instáveis nas áreas de reabilitação e condicionamento físico geral têm sido eficaz no aumento da eficiência sensorial dos tecidos moles que estabilizam o joelho e tornozelo e na melhora da cocontração agonistaantagonista. Desta forma, o objetivo deste estudo foi analisar a atividade eletromiográfica dos músculos tibial anterior (TA), fibular longo (FL) e cabeça medial do gastrocnêmio (GM) durante o exercício proprioceptivo com bosu e comparar com diferentes aparelhos tradicionalmente utilizados (balancinho, cama elástica e disco proprioceptivo). Onze voluntários do gênero masculino foram recrutados e a coleta de dados foi realizada utilizando-se eletrodos de superfície diferencial simples. O sinal eletromiográfico foi quantificado pela Raiz Quadrada da Média (root mean square -RMS) e normalizado pela Contração Isométrica Voluntária Máxima. Os dados obtidos foram submetidos à análise estatística paramétrica, empregando-se teste de análise de variância de medidas repetidas (ANOVA). Os resultados demonstraram que o bosu proporcionou maior atividade nos músculos do tornozelo em relação a maioria dos aparelhos proprioceptivos , desta 
forma, o bosu é um dispositivo que deve ser utilizado para diversificar um programa de prevenção ou reabilitação de lesões de membro inferior, preferencialmente em estágios avançados destes programas.

PALAVRAS-CHAVE: Balancinho. Disco proprioceptivo. Cama elástica. Eletromiografia.

\section{REFERENCES}

AGUIAR, A. P. Análise eletromiográfica e do lactato sanguíneo em exercício resistido incremental. 2006. 146f. Dissertação (Mestrado em Fisioterapia) - Faculdade de Ciências da Saúde, Universidade Metodista de Piracicaba, Piraciba, 2006.

ANTES, D. L.; KATZER, J. I.; CORAZZA, S. T. Coordenação motora fina e propriocepção de idosas praticantes de hidroginástica. Revista Brasileira de Ciências do Envelhecimento Humano, Passo Fundo, v. 5, n. 2, p. 24-32, 2008.

BASMAJIAN J.V., DE LUCA C.J. Muscles alive: their function revealed by electromyography. 5. ed. Baltimore: Williams and Wilkins, 1985.

BEHM, D. G.; DRINKWATER, E. J.; WILLARDSON, J. M.; COWLEY, P. M. The use of instability to train the core musculature. Applied Physiology, Nutrition, and Metabolism, Ottawa, v. 35, p. 91-108, 2010. https://doi.org/10.1139/H09-127

BEHM, D.; SANCHEZ, J. C. C. The effectiveness of resistance training using unstable surfaces and devices for rehabilitation. The International Journal of Sports Physical Therapy, Indianapolis, v. 7, n. 2, p. 226-241, 2012.

BLACKBURN, J. T.; HIRTH, C. J.; GUSKIEWICZ, K. M. Exercise Sandals Increase Lower Extremity Electromyographic Activity During Functional Activities. Journal of Athletic Training, Dallas, v. 38, n. 3, p. 198-203, 2003.

BROWN, L. E. Treinamento de força/National Strength and Conditioning Association. Barueri: Manole; 2008.

CALLEGARI, B.; RESENDE, M. M.; RAMOS, L. A. V.; BOTELHO, L. P.; ALBUQUERQUE, S. A. Electromyographic activity during ankle proprioception exercises on one-foot stance. Fisioterapia e Pesquisa, São Paulo, v. 17, n. 4, p. 312-316, 2010. https://doi.org/10.1590/S1809-29502010000400005

EVANGELISTA, A. L.; MACEDO, J. Treinamento funcional e core training: exercícios práticos aplicados. São Paulo: Phorte, 2011.

FEGER, M. A.; DONOVAN, L.; HART, J. M.; HERTEL, J. Lower extremity muscle activation in patients with or without chronic ankle instability during walking. Journal of Athletic Training, Dallas, v. 50, n. 4, p. 350-357, 2015. https://doi.org/10.4085/1062-6050-50.2.06

FERREIRA, L. A. B.; PEREIRA, W. M.; ROSSI, L. P.; KERPERS, I. I.; PAULA JÚNIOR, A. R.; OLIVEIRA, C. S. Analysis of electromyographic activity of ankle muscles on stable and unstable surfaces with eyes open and closed. Journal of Bodywork \& Movement Therapies, New York, v. 15, p. 496-501, 2011. https://doi.org/10.1016/j.jbmt.2010.09.003

FERREIRA, L. A. B. Análise da atividade eletromiográfica dos músculos do tornozelo em solo estável e instável com os olhos abertos e fechados. 2009. 93 f. Dissertação (Programa de Pós-Graduação em Bioengenharia do Instituto de Pesquisa e Desenvolvimento), Universidade do Vale do Paraíba, São José dos Campos, 2009. 
FERREIRA, L. A. B.; ROSSI, L. A. B.; PEREIRA, W. M.; VIEIRA, F. F.; PAULA JÚNIOR, A. R. Análise da atividade eletromiográfica dos músculos do tornozelo em solo estável e instável. Fisioterapia em Movimento, Curitiba, v. 22, n. 2, p. 177-187, 2009.

FRANCO, N. R.; AMAT, A. M. ; LÓPEZ, E. J. M. Effect of the proprioceptive training in sprinters. Revista Internacional de Medicina y Ciencias de la Actividad Física y el Deporte, v. 13, n. 51, p. 437-451, 2013.

HERMENS, H. J.; FRERIKS, B. The SENIAM cd-rom: European recommendations for surface electromyography. Netherlands: Roessingh Research and Development, 1999. 1 CD.

KONRAD, P. The ABC of EMG: A Practical Introduction to Kinesiological Electromyography. Noraxon INC. USA.; 2005.

LAUDNER, K. G.; KOSCHNITZKY, M. M. Ankle muscle activation when using the both Sides utilized (bosu) balance trainer. Journal of Strength and Conditioning Research, Champaign, v. 24, p. 218-222, 2010. https://doi.org/10.1519/JSC.0b013e3181c490d4

MARTINS, C. N.; TAROUCO, C. P.; MARTIN, D. G.; SIGNORI, L. U. Eletromiografia do reto femoral em diferentes equipamentos proprioceptivos no meio aquático. Revista Brasileira de Medicina do Esporte, São Paulo, v. 20, n. 4, p. 289-293, 2014. https://doi.org/10.1590/1517-86922014200401985

NEEDLE, A. R.; SWANIK, C. B. ; FARQUHAR, W. B.; THOMAS, S. J.; ROSE, W. C.; KAMINSKI, T. W. Muscle Spindle Traffic in Functionally Unstable Ankles During Ligamentous Stress. Journal of Athletic Training, Dallas, v. 48, n. 2, p. 192-202, 2013. https://doi.org/10.4085/1062-6050-48.1.09

NETTER, F. H. Atlas de Anatomia Humana. 2. ed. Porto Alegre: Artmed, 2000.

OLIVEIRA, D. C. S.; REZENDE, P. A. M. S. L.; SILVA, M. R.; LIZARDO, F. B.; SOUSA, G. C.; SANTOS, L. A.; GUIMARÃES, E. A.; CHACUR, E. P. Electromyographic analysis of lower limb muscles in proprioceptive exercises performed with eyes open and closed. Revista Brasileira de Medicina do Esporte, São Paulo, v. 18, n. 4, p. 261-266, 2012. https://doi.org/10.1590/S1517-86922012000400009

OLIVER, G. D.; DWELLY, P. M.; SARANTIS, N. D.; HELMER, R. A.; BONACCI, J. A. Muscle activation of different core exercises. Journal of Strength and Conditioning Research, Champaign, v. 24, n. 11, p. 3069-3074, 2010. https://doi.org/10.1519/JSC.0b013e3181d321da

PECCIN, M. S.; PIRES, L. Reeducação sensóriomotora. In: COHEN, M.; ABDALLA, R. J. Lesões nos esportes: diagnóstico, prevenção e tratamento. Rio de Janeiro: Revinter; 2003.

RENSTRÖM, A. F. H. ; LYNCH, S. A. Lesões ligamentares do tornozelo. Revista Brasileira de Medicina do Esporte, São Paulo, v. 5, n. 1, p. 13-23, 1999. https://doi.org/10.1590/S1517-86921999000100004

STEIB, S.; ZECH, A.; HENTSCHKE, C.; PFEIFER, K. Fatigue-Induced Alterations of Static and Dynamic Postural Control in Athletes With a History of Ankle Sprain. Journal of Athletic Training, Dallas, v. 48, n. 2, p. 203-208, 2013. https://doi.org/10.4085/1062-6050-48.1.08

YAGGIE, J. A. ; CAMPBELL, B. M. Effects of balance training on selected skills. Journal of Strength and Conditioning Research, Champaign, v. 20, n. 2, p. 422-428, 2006. https://doi.org/10.1519/R-17294.1 https://doi.org/10.1519/00124278-200605000-00031 